\title{
A new combination in Asteropsis (Compositae: Astereae), and a synopsis of the genus
}

\author{
Jose M. Bonifacino ${ }^{1}$, Gisela Sancho ${ }^{2}$, And Eduardo H. Marchesi ${ }^{3}$ \\ ${ }^{1}$ Laboratorio de Botánica, Facultad de Agronomía, Casilla de Correos 1238, Montevideo, Uruguay; \\ e-mail: bonifacinoj@fagro.edu.uy \\ ${ }^{2}$ División Plantas Vasculares, Museo de La Plata, Paseo del Bosque s. n., La Plata, 1900, \\ Buenos Aires, Argentina; e-mail: sancho@fcnym.unlp.edu.ar \\ ${ }^{3}$ Laboratorio de Botánica, Facultad de Agronomía, Casilla de Correos 1238, Montevideo, Uruguay; \\ e-mail: ehmarch@gmail.com
}

\begin{abstract}
A new combination, Asteropsis megapotamica, is made after studying specimens at Paris (P). A taxonomic revision of Asteropsis, with detailed descriptions, drawings, and images of $A$. megapotamica is presented. A lectotype for Neja macrocephala is designated. A discussion about generic relationships of Asteropsis and closely related genera is provided.
\end{abstract}

Key Words: Asteropsis megapotamica, new combination, Brazil, Podocominae, Uruguay.

The rare and geographically restricted monotypic genus Asteropsis Less. (Compositae: Astereae) is endemic to southern Brazil and northern Uruguay, and was originally described, along with its sole species Asteropsis macrocephala Less., by Lessing (1832).

Independently, and based on different material from Rio Grande do Sul, Hooker and Arnott (1836) published Podopappus tomentosus Hook. \& Arn. to refer to the same taxon coined by Lessing as Asteropsis macrocephala. Later on, Bentham (1873) placed Asteropsis in the synonymy of Podocoma Cass.; however, he did not make the combination. It was up to Herter (1930) to publish the combination Podocoma macrocephala (Less.) Herter, as suggested by Bentham.

Nevertheless, in his treatment of Brazilian Astereae, Baker (1882) recognized Asteropsis as a distinct genus, just as more recent authors do (Nesom, 1994a; Sancho et al., 2006; Nesom \& Robinson, 2007; Sancho \& Karaman-Castro, in press; Brouillet et al., in press). After having had access to type material of South American Astereae from the Herbarium of Muséum National d'His- toire Naturelle $(\mathrm{P})$ described by Sprengel (1826), it has become evident to us that Aster megapotamica Spreng. refers to the same taxonomic entity described by Lessing under Asteropsis. Therefore, both names should be considered heterotypic synonyms, with Sprengel's name having priority over Lessing's.

Here, we present a new combination for Asteropsis and provide its taxonomic revision with detailed descriptions, drawings, and images of its only species, $A$. megapotamica.

\section{Material and methods}

Data is derived from the study of herbarium specimens from BM, K, LP, MVFA, P, SI, and US, and from field observations. For light microscopic examination, floral and vegetative parts were re-hydrated and stained in $2 \%$ safranin. Involucre shape and measurements were made on live specimens. Drawings were made by the authors using a Wild M3Z stereo microscope and a Leitz SM Lux microscope with camera lucida. Terminology follows Harris and Harris (1994), Ramayya (1962), and Stearn (1995). 


\section{Generic relationships}

After its original description, Asteropsis was sunken into synonymy with Podocoma by Bentham (1873). This was followed by several authors including Zhang and Bremer (1993) who incorporated Podocoma into their Hinterhubera group (i.e., Blakiella Cuatrec., Flosmutisia Cuatrec., Hinterhubera Sch. Bip., Microgyne Less., and Westoniella Cuatrec.). These authors based their inclusion of Podocoma on the presence of beaked cypselae, a character that, of the five genera in the group, was only shared with Blakiella. Bremer (1994) followed Zhang and Bremer (1993) in regards to the relationships of Podocoma. However, recent morphological and molecular evidence (Karaman, 2006; Nesom \& Robinson, 2007; Sancho \& Karaman-Castro, in press) have shown that the beaked cypselae of Blakiella and Podocoma originated independently.

Nesom (1994a) regarded Asteropsis as a distinct genus. $\mathrm{He}$ also provided the first detailed synonymy for this genus, accounting for most of the names ascribed to A. macrocephala, and commented on its putative phylogenetic relationships, naming Podocoma, Microgyne, Sommerfeltia Less., Inulopsis (DC.) O. Hoffm., Rhabdanthus G. L. Nesom, Laennecia Cass., and Blakiella as its closest relatives. When the subtribe Podocominae was described by Nesom (1994b), he included Asteropsis, other South American genera such as Blakiella, Inulopsis, Laennecia, Podocoma, and Sommerfeltia, and a group of Australasian genera. The genus Blakiella was later transferred to the subtribe Hinterhuberinae (Nesom \& Robinson, 2007).

Morphological and molecular phylogenetic studies partially agree with the generic relationships of Asteropsis suggested by Nesom and Robinson (2007). In recent studies, Asteropsis forms an assemblage with Inulopsis, Microgyne, and Sommerfeltia, and among those genera, the closest relationship of Asteropsis is with Inulopsis (Sancho \& Karaman-Castro, in press; Brouillet et al., in press). Close phylogenetic relationships between Podocoma and Asteropsis were not demonstrated in these phylogenetic studies. Morphologically, Asteropsis differs from Podocoma by its densely leafy stems, solitary, strongly radiate capitula, and cypselae that are attenuate towards the apex (vs. sparsely leafy stems, corymbiform capitulescences of few heads, sub-radiate capitula, and truly rostrate cypselae in Podocoma).

Among the South American genera of Podocominae, Asteropsis, Inulopsis, Microgyne, and Sommerfeltia share radiate capitula, usually sterile, non-rostrate, disk cypselae, and a pappus of (1)2 or 3 series of bristles. Morphologically, Inulopsis shares with Asteropsis glandular cypselae with an attenuate apex (abruptly attenuate in Inulopsis and gradually attenuate in Asteropsis). Asteropsis and two species of Inulopsis (I. scaposa (DC.) O. Hoffm., I. stenophylla Dusén) also share a pappus with an outermost series of very short bristles. Inulopsis differs from Asteropsis by its single-seriate ray florets with relatively wide corolla limbs (vs. 3- or 4-seriate ray florets with narrow corolla limbs in Asteropsis).

We follow Sancho and Karaman-Castro (in press) and Brouillet et al. (in press) in considering three genera of the current Podocominae (Inulopsis, Microgyne, and Sommerfeltia) as most closely related to Asteropsis, and present a key to differentiate these genera.

\section{Key to Asteropsis and related genera}

1. Plants unbranched or only branched at the base; leaves linear, narrowly elliptic or obovate to widely obovate with margins mostly entire (lowermost leaves with lobed margins in Asteropsis); cypselae attenuate at apex.

2. Ray florets in 1 (2) series, ray corollas with relatively wide limbs, (1-)1.5-2.5 mm wide; cypselae abruptly

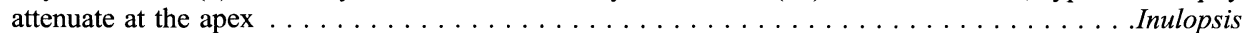

2. Ray florets in 3 or 4 series, ray corollas with relatively narrow limbs, up to $1 \mathrm{~mm}$ wide; cypselae gradually

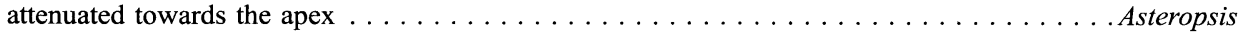

1. Plants shrubby, fully branched; leaves elliptic (in outline) with pinnatifid margins; cypsela apex truncate or with confluent margins.

3. Leaves soft; capitula solitary; cypselae of disk florets eglandular and fertile 
3. Leaves rigid; capitula often in racemiform capitulescences; cypselae of disk florets glandular and

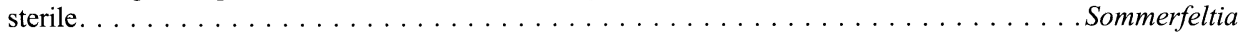

\section{Taxonomic treatment}

Asteropsis Less., Syn. Gen. Compos. 188, 1832. Neja sect. Phylloneja DC., Prodr. 5: $325,1836$.

Perennial herbs, hemicryptophytes, lignotubers elongate, stems erect, basally branched or simple. Leaves densely disposed, alternate, spirally arranged, narrowly elliptic to narrowly obovate, sessile, apex subacute, base attenuate, glandular and woolly-villous on both surfaces, margins entire. Capitula solitary (less commonly 2 or 3), terminal, sessile, heterogamous, radiate. Involucres hemispheric to globose; phyllaries in 5 or 6 series, glandular and villous on both surfaces. Receptacles epaleate. Ray florets 3- or 4seriate, pistillate, corollas white, true rays with long limbs, style branches linear. Disk florets numerous, bisexual (functionally male), corolla actinomorphic, 5-lobed; anther base slightly sagittate, apical appendages ovate; style branches narrowly triangular to oblong, totally dorsally covered by sweeping hairs. Cypselae flattened, strongly 2-nerved, gradually attenuate towards the apex, glandular throughout its surface and villous mainly on the margins, cypselae of disk florets noticeably thinner, with or without a developed ovule. Pappus of 2 or 3 series of scabrid bristles, sometimes with some outermost bristles very short.

Asteropsis megapotamica (Spreng.) Marchesi, Bonifacino \& Sancho, comb. nov. Aster megapotamicus Spreng., Syst. veg. 3: 526, 1826. Type: [Brazil. Rio Grande: sine loc.] Spreng. herb. 1164, Sello s.n. (holotype: P).

(Figs. 1, 2)

Asteropsis macrocephala Less., Syn. gen Compos. 188, 1832. Podocoma macrocephala (Less.) Herter, Florula Urug. Pl. vasc. 123, 1930. Type: [Brazil.] Est. Maxada, April 1823, Sello [1853?] (holotype $\mathrm{B}$, destroyed; photo: F-14909; isotypes: BM, K, P).
Podopappus tomentosus Hook. \& Arn., Comp. Bot. Mag. 2: 51, 1836. Type: Brazil. Rio Grande do Sul: M. Isabelle s.n. (holotype: K?, n.v.).

Neja macrocephala DC., Prodr. 5: 325, 1836. Type: Brazil. Rio Grande do Sul: 1833, Herbier Impérial du Brésil 1047, Gaudichaud s.n. (lectotype, here designated: P).

Perennial herbs, hemicryptophytes, lignotubers elongate, cylindrical, $0.5-1 \mathrm{~cm}$ in diameter, stems $30-45 \mathrm{~cm}$ tall, erect, basally branched or with only one branch, the branches long. Leaves densely disposed, alternate, spirally arranged, 15-35 $\times 1$ $3 \mathrm{~mm}$, narrowly elliptic to narrowly obovate, sessile, apex sub-acute, base attenuate, glandular (vesicular biseriate trichomes, notably sunken on epidermis) and woolly-villous (flagellate-septate trichomes) on both surfaces, margins entire, the basal leaves with one or two pair of lobes. Capitula solitary (rarely grouped in 2- or 3-headed capitulescences), terminal, sessile, heterogamous, radiate. Involucres $12-20 \times 20-25 \mathrm{~mm}$, hemispheric to globose; phyllaries in 5 or 6 series, tips reddish, outer phyllaries 7-9 × 0.7-1.1 mm, narrowly elliptic to linear, subulate, margin membranous, glandular and woolly-villous on both surfaces; inner phyllaries 10-13 $\times$ 1-1.2 mm, linear, apex subulate, margin membranous, glandular and woolly-villous on abaxial surface, glabrous or with little glandular-villous pubescence towards the apex on adaxial surface. Receptacles epaleate, with short scales. Ray florets arranged in 3 or 4 series, 100-150, pistillate, corollas white, true ray, tube ca. $4 \mathrm{~mm}$ long, limb ca. $17 \times 1 \mathrm{~mm}$, linear, minutely 2- or 3-lobed; style ca. $4.5 \mathrm{~mm}$ long, style branches 2-2.2 mm long, linear. Disk florets ca. 150, bisexual (functionally male), corolla yellow, actinomorphic, 5-lobed, subcampanulate, tube ca. $2 \mathrm{~mm}$ long, throat $3.5-4 \mathrm{~mm}$ long, tube and throat laxly glandular (biseriate glandular trichomes), lobes ca. $1 \times 0.5-0.6 \mathrm{~mm}$, triangular, glandular (vesicular biseriate glandular trichomes) towards the apex; anthers ca. $2 \mathrm{~mm}$ long, antheropodium present ca. $0.6 \mathrm{~mm}$ long, anther base slightly sagittate, apical 


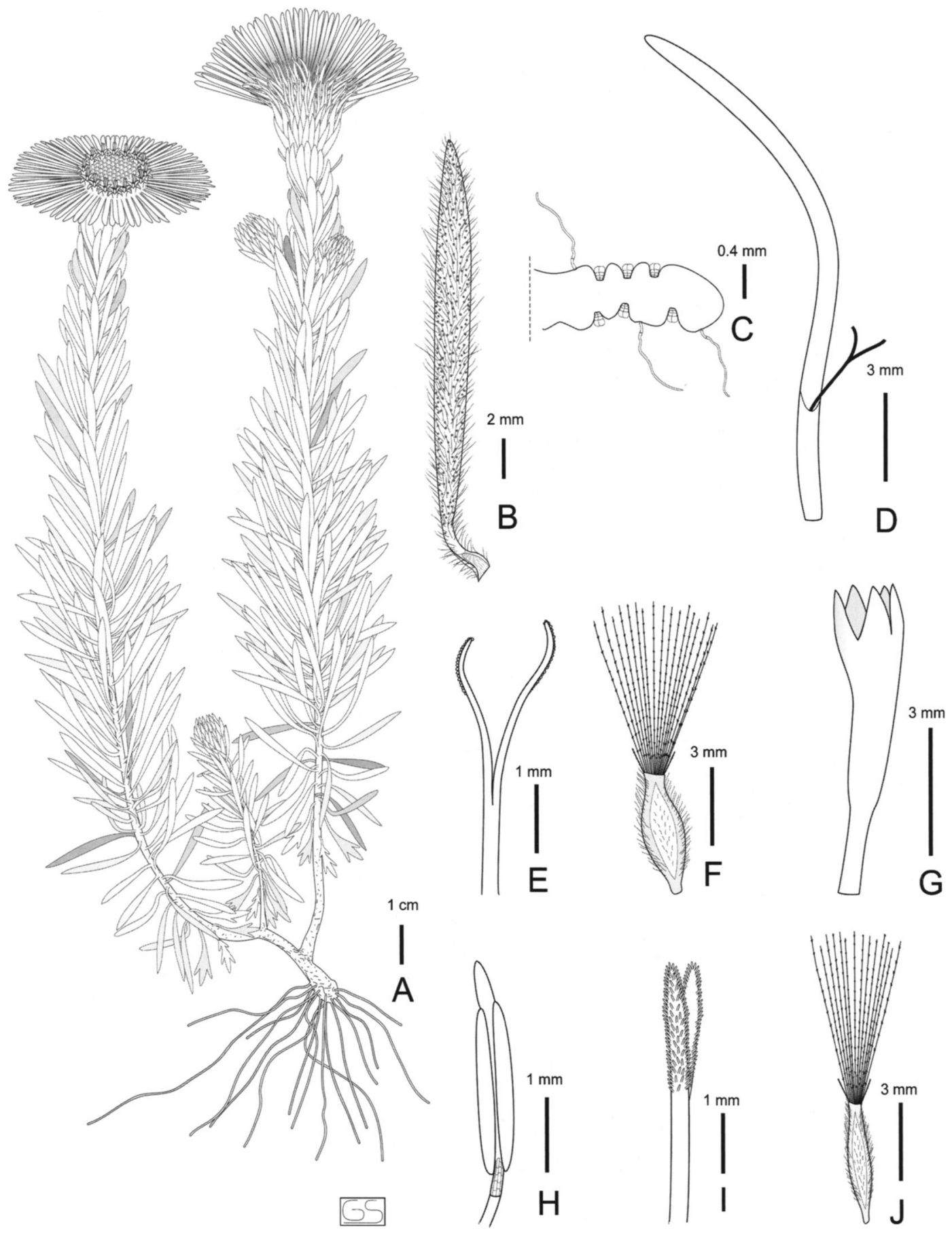

Fig. 1. Asteropsis megapotamica. A. Habit. B. Leaf. C. Cross section of leaf showing sunken, vesicular, biseriate, glandular trichomes and flagellate-septate trichomes. D. Ray corolla with style. E. Style of ray corolla (distal part). F. Cypsela of ray floret with pappus. G. Disk corolla. H. Stamen. I. Style of disk floret (distal part). J. Cypsela of disk floret with pappus. (A from Rosengurtt B7089, MVFA; B-J from Cabrera \& Zuloaga 32376, LP.) 

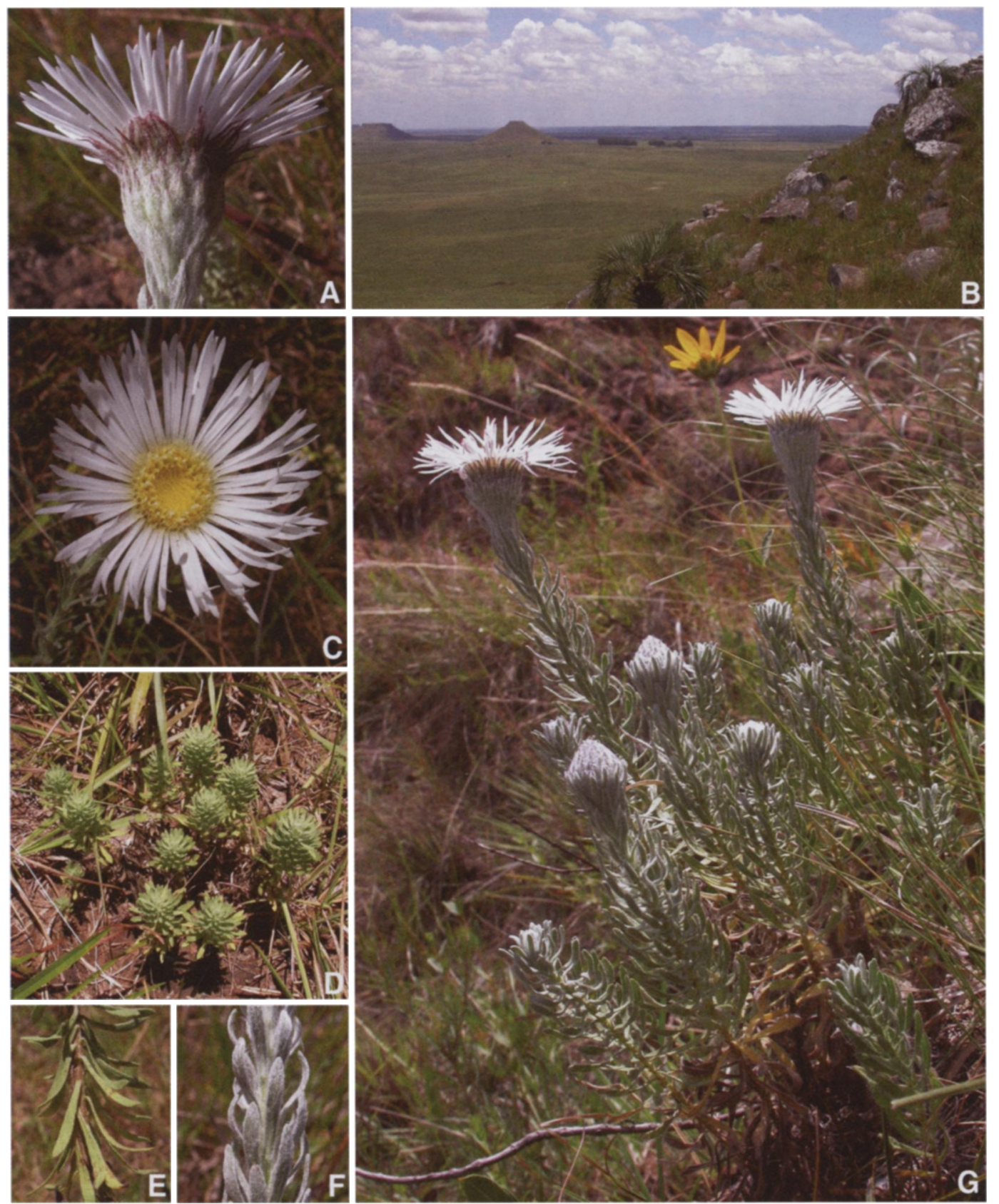

Fig. 2. Asteropsis megapotamica. A. Detail of capitulum showing the woolly involucre. B. Rocky habitats of Asteropsis showing flat topped hills characteristic of northwestern Uruguay. C. Detail of the showy and radiate capitulum. D. Clumps of plants of Asteropsis, soon after re-starting vegetative growth. E. Proximal leaves. F. Distal leaves. G. Asteropsis in its habitat.

connectival appendages ca. $0.6 \times 0.3 \mathrm{~mm}$, ovate, style ca. $5 \mathrm{~mm}$ long, style branches ca. $2 \mathrm{~mm}$ long, narrowly triangular to oblong, whole abaxial surface covered by sweeping hairs. Cypselae 4-4.5 $\mathrm{mm}$ long, elliptic, flattened, strongly 2-nerved, gradually attenuated towards the apex, glandular throughout its surface, and villous mainly on the margins. 
Pappus ca. $7 \mathrm{~mm}$ long, of 2 or 3 series of scabrid, subequal bristles, sometimes with some outermost bristles very short, $1 \mathrm{~mm}$ long, all bristles tapering, somewhat flattened at the base.

Distribution and ecology.-Asteropsis is distributed in northern Uruguay (Rivera and Tacuarembó) and southern Brazil (Rio Grande do Sul). In Uruguay, Asteropsis megapotamica occurs on rocky grasslands and slopes of riverbeds amid sparse shrubs of Baccharis spp., Eupatorium spp., Heterothalamus alienus (Spreng.) Kuntze, Vernonanthura nudiflora (Less.) H. Rob., and Butia paraguariensis (Barb. Rodr.) L. $\mathrm{H}$. Bailey ("dwarf butia" palms, Fig. 2B). In certain locations, it is possible to see abundant clumps of Asteropsis in grass-like vegetation dominated by the also rare and geographically very restricted Schlechtendalia luzulaefolia Less. From a geomorphologic point of view, the habitat of Asteropsis (in northwestern Uruguay) is very interesting since the species grows intimately associated with flat-topped hills (Fig. 2B), a rather dramatic landscape feature of Gondwanic origin. According to Bossi et al. (1998), the flat-topped hills ("cerros chatos") that characterize northwestern Uruguay are constituted by sandstone belonging to Tacuarembó and Rivera geological formations that were formed during the Jurassic. These sandstone formations are composed of medium to fine-grain sand as well as some kaolinite clay elements, and extend past the Uruguayan borders into Brazil where Asteropsis also occurs. In Brazil, Asteropsis megapotamica has been found on sandy soils of "campos" formations in Rio Grande do Sul, an area mostly dominated by grasslands.

Phenology.-Asteropsis megapotamica regains activity producing branches and leaves starting at the beginning of October and flowers and fruits from January to April.

Candolle (1836) cites three specimens in the protologue, all of which perfectly match the original diagnosis, and we select "Herbier Impérial du Brésil 1047, Gaudichaud" as lectotype because it is a fairly complete specimen with unambiguous label information. The photograph of the Sello specimen from $\mathrm{B}$ at $\mathrm{F}$ shows a label with the probable collector number, 1853.

Additional specimens examined. BRAZIL. RIO Grande Do Sul:Tupareceta, 8 Mar 1939, Avila de Araujo 28 (LP); 1833, Herbier Impérial du Brésil 1001, Gaudichaud s.n. (P); 1833, Herbier Impérial du Brésil 1006, Gaudichaud s.n. (P); Cruz Alta, 4 Dec 1893, Malme s.n., Exped. Primae Regnellian Phanerogamae 7289 (BM); Porto Alegre, Aug 1951, Mokrdieck 2 (LP); Cruz Alta, 23 Jan 1964, Pereira \& Pabst 8494, 7869 (LP); without precise locality, 19 Jan 1940, Rau s.n. (SI 25562).

URUGUAY. RIVERA: Subida de Pena, Ruta $30, \mathrm{~km}$ 111.5, 11 Apr 1984, Bayce et al. s. n. (MVFA 17278); 5 $\mathrm{km}$ al E de Ruta 5, Cerro Miriñaque, 10 Apr 1984, Bayce et al. s.n. (MVFA 17226); Cerro Alegre, $12 \mathrm{~km}$ al S de Tranqueras, 13 Apr 1984, Bayce et al. s.n. (MVFA 17340); Cerro Hospital, 19 Dec 1901, Berro 5111 (K, MVFA); Ruta 30, próximo a subida de Pena, $31^{\circ} 8^{\prime} 51^{\prime \prime}$ S, 55 53' 53" W, 15 Jan 2006, Bonifacino 2130 (MVFA); Entre Paso Vargas y Paso Platón, 15 Mar 1962, Del Puerto 1747 (MVFA); Estancia Ripoll, Ruta 5, próximo a Ruta 29, 28 Feb 1962, Del Puerto 1523 (MVFA); Valle Arroyo Platon, próximo a Escuela 56, 20 Feb 1966, Marchesi 1442 (MVFA); Picada de Castro, Escuela Agraria, 30 Jan 1958, Rosengurtt B7089 (MVFA); Cerro Aurora, 10 Dec 1961, Rosengurtt B8404 (MVFA). TACuAREMbo: Gruta de Los Cuervos, 8 Feb 1981, Cabrera \& Zuloaga 32376 (LP, SI); Quebrada de los Cuervos, Jan 1940, Chebataroff 10317 (LP); Gruta de los Cuervos, 9 Mar 1966, Rosengurtt et al. 10035 (MVFA, US); Gruta de Los Cuervos, $20 \mathrm{Feb}$ 2004, Sancho \& Bonifacino 99, 100 (LP, MVFA).

\section{Acknowledgments}

We thank Dan Nicolson for useful advice in nomenclature matters. We are also grateful to the curators of BM, K, LP, MVFA, P, SI, and US who provided material for examination. Research for this article was supported by Facultad de Agronomía (JMB, EM), Myndel Pedersen Foundation (JMB), Smithsonian Institution (JMB), and Agencia Nacional de Promoción Científica y Tecnológica, SECYT, Argentina (GS).

\section{Literature Cited}

Baker, J. G. 1882. Compositae III. Asteroideae \& Inuloideae. In: C. F. P. Martius \& A. G. Eichler (eds.), Flora Brasiliensis, 6 (2): 1-134. Fleischer, Munich, Viena, Leipzig.

Bentham, G. 1873. Compositae. In: G. Bentham \& J. D. Hooker (eds.), Genera plantarum, 2: 163-533. Lovell Reeve and Co., London.

Bossi, J., L. A. Ferrando, J. Montaña, N. Campal, H. Morales, F. Gancio, A. Schipilov, P. Sprechman \& 
D. Piñeyro. 1998. Carta Geológica del Uruguay a escala 1/500.000 - 1998. Ed. Geoeditores S.R.L., Montevideo.

Bremer, K. 1994. Asteraceae: Cladistics and classification. Timber Press, Portland: Oregon.

Brouillet, L., T. Lowrey, L. E. Urbatsch, S. J. Wagstaff, V. Karaman \& G. Sancho. In press. Molecular phylogeny and biogeography of tribe Astereae: In: V. A. Funk, A. Susanna, T. Stuessy \& R. Bayer (eds.), Systematics, Evolution, and Biogeography of the Compositae. IAPT, Vienna, Austria.

Candolle A. P. de. 1836. Prodromus systematis naturalis regni vegetabilis, 5. Treuttel and Würtz, Paris.

Harris, J. G. \& M. W. Harris. 1994. Plant identification terminology. An illustrated glossary. Spring Lake Publishing, Spring Lake.

Herter, G. 1930. Florula uruguayensis. Plantae vasculares. (Estudios Botánicos en la Región Uruguaya, 4.). Montevideo.

Hooker, W. J. \& G. A. W. Arnott. 1836. Contributions towards a flora of South America and the islands of the Pacific. Companion to the Botanical Magazine 2: 41-52.

Karaman V. 2006. Phylogeny of Hinterhubera, Novenia and related genera based on the nuclear ribosomal (nr) DNA sequence data (Asteraceae: Astereae). Ph.D. dissertation, Louisiana State University, Baton Rouge, USA.
Lessing, C. F. 1832. Synopsis Generum Compositarum earumque dispositionis novae tentamen monographs multarum capensium interjectis. Berlin.

Nesom G. L. 1994a. Comments on Microgynella, Sommerfeltia, and Asteropsis (Asteraceae: Astereae). Phytologia 76: 101-105.

. 1994b. Subtribal classification of the Astereae (Asteraceae). Phytologia 76: 193-214.

\& H. Robinson. 2007. Astereae. In: K. Kubitzki (ed.), Families and Genera of Vascular Plants, 3: 284 342. Flowering Plants - Eudicots - Asterales. Springer, Verlag.

Ramayya, N. 1962. Studies on the trichomes of some Compositae I. General structure. Bulletin of the Botanical Survey of India 4: 177-188.

Sancho G., J. M. Bonifacino \& J. Pruski. 2006. Revision of Microgyne (Asteraceae: Astereae), the Correct Name for Microgynella. Systematic Botany 31: 851-861.

Sancho, G. \& V. Karaman-Castro. In press. A phylogenetic study in South American Podocominae (Asteraceae: Astereae) based on morphological and molecular Data. Systematic Botany.

Sprengel, C. 1826. Systema vegetabilium, ed. 16, 3, Classis 16-23. Gottingae.

Stearn, W. T. 1995. Botanical Latin: history, grammar, syntax, terminology and vocabulary, ed. 4. Timber Press, Portland, Oregon. 